Journal of Education and Science (ISSN 1812-125X), Vol: 30, No: 3, 2021 (117-132)

Special Issue for Proceeding of $3^{\text {rd }}$ National (1 $1^{\text {st }}$ international conference of biology) (ICBSUM 2021) 5, 6 July

College of Education for Pure Science, University of Mosul, Mosul, Iraq.

\title{
Molecular diagnosis of rhizobia isolated from the root of some leguminous plants
}

\author{
Mohammed Abdelilah Al-Shakarchi ${ }^{1 *}$, Najwa Ibrahim Al-Barhawi ${ }^{2}$, Khalid Daham Ahmed ${ }^{3}$ \\ ${ }^{1 * 2,3}$ Department of Biology, Education College for Pure Science, University of Mosul, Mosul, Iraq \\ E-mail: ${ }^{1 *}$ dr.mohammedsh@uomosul.edu.iq, ${ }^{2}$ dr.najwa@uomosul.edu.iq, ${ }^{3}$ khalid.d.a@ gmail.com
}

(Received April 21, 2021; Accepted June 18, 2021; Available online August 28, 2021)

DOI: 10.33899/edusj.2021.168642, (c) 2021, College of Education for Pure Science, University of Mosul.

This is an open access article under the CC BY 4.0 license (http://creativecommons.org/licenses/by/4.0/).

\begin{abstract}
Rhizobia represents one of the most important types of beneficial soil bacteria, as it contributes to fixing atmospheric nitrogen. In the present study, twenty four isolates of rhizobial bacteria were isolated from root nodules of six leguminous plants. These are Medicago sativag Trigonella foenumgraecum, Cicer arietinum, Vicia faba, Lens culinaris and Lupinus spp. which planted in four regions of Ninevah province (wire farm house in the Education College / Mosul University , Ba'shiqah town and Sadaa \& Bauazh) for the agricultural season 2010-2011. These isolates were put in six groups depending on diagnostic tests and type of plant host (alfalfa, fenugreek, chickpeas, bean, lentils and lupine) from which the bacteria isolated from their root nodules. These groups are $\mathrm{RhM}, \mathrm{RhT}, \mathrm{RhC}, \mathrm{RhF}, \mathrm{RhL}$ and RhLu respectively.

RAPD - PCR technique with four random primers were used to draw the genetic Dendrogram in order to demonstrate the relationships among the species of rhizobial bacteria isolated from the root nodules of different host. The results revealed that there are genetic diversity among these species and also diversity still exist among the isolates of the same species but at low level. According to the results of diagnostic tests, RAPD - PCR technique and specificity of rhizobial bacteria to infect their hosts, we can relate the isolates in the suggested groups to their scientific names as follow: Sinorhzobium meliloti (RhM) , Sinorhzobium meliloti (RhT) , Rhizobium legumenosarum bv. cecir (RhC) , Rhizobium legumenosarum bv. vicia (RhF), Rhizobium legumenosarum bv. lentil (RhL), Rhizobium lupini (RhLu).
\end{abstract}

Key word: Rhizobia, RAPD-PDR

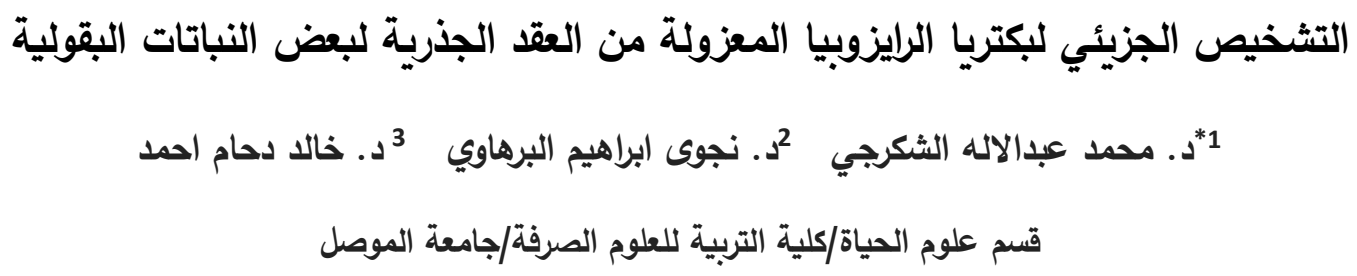

Downloaded from https://edusj.mosuljournals.com/ 
تمثل بكتريا الرايزوبيا احد اهم أنواع بكتريا التربة المفيدة كونها تساهم في تثبيت النتروجين الجوي ففي الدراسة الحالية تم عزل اربعة وعشرون عزلة لبكتريا الرايزوبيا من العقد الجذرية لستة من نباتات العائلة البقولية وهي Medicago sativa و Trigonella

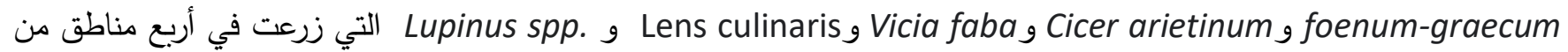
محافظة نينوى وهي (البيت السلكي في كلية التربية/جامعة الموصل ومزرعتان تابعتان لناحية بعشيقة ومزرعة في منطقة سادة وبعويزة) للموسم الزراعي 2010-2011 م. وصنفت عزلات بكتريا الرايزوبيا إلى ستة مجاميع بالاعتماد على الفحوصات التشخيصية ونوع العائل النباتي الذي عزلت منه (الجت والحلبة والحمص والباقلاء والعدس والترمس) وهذه المجاميع هي RhM و RhT و RhC و RhF و Random Amplified Polymorphism ع على التوالي. أستخدمت تقانة تقاعلات مؤشرات التضاعف العشوائي RhL و Rو (RAPD-PCR) DNA المدروسة والمعزولة من مضائف مختلفة وأن هذا التباين لازال موجوداً بين عزلات بكتريا النوع الواحد والمعزولة من العقد الجذرية من النباتات البقولية المزروعة في مناطق مختلفة ولكن بمستوى أدنى.

واستتاداً إلى نتائج الفحوصات التشخيصية وتقانة الـ(RAPD - PCR) وخصوصية اصابة البكتريا للعائل الخاص بها فقد سميت

العزلات البكتيرية في المجاميع المذكورة اعلاه بتسمياتها العلمية: Sinorhzobium meliloti (RhM) و Sinorhzobium meliloti و Rhizobium legumenosarum bv. vicia (RhF) g Rhizobium legumenosarum bv. cecir (RhC) و (RhT) Rhizobium lupini (RhLu) و Rhizobium legumenosarum bv.lentil (RhL) الكلمات المفتاحية: الرايزوبيا ، التفاعل التضاعف العشوائي 1. 1 تعد العائلة البقولية Leguminaceae من اكبر العائلات النباتية فهي تضم عدد كبير من النباتات العشبية والشجيرات والاشجار إذ وضـت تحت رتبة Leguminalse التي تنضوي تحتها عائلات ثلاثة هي: البقلية Caesalpiniaceae ، والسنطيات Mimosaceae ، الفراشية Pabilionaceae والمعروفة ايضا باسم Fabaeae [1]. تضم العائلة البقولية عددا كبيرا من محاصيل الخضـر والمحاصـيل الحقليـة التـي تنتشـر زراعتهـا في جميـع انحـاء العـالم والمعروفـة باهميتهـا الاقتصـادية والغذائيـة منهـا الجـت و Cicer arietinum L. والحمص Trigonella foenum-graeum والحلبة Trifolium spp. البرسية Medicago sativa L. الباقلاء Licia faba و العدس Lens esculentus والترمس .Lupinus spp. افراد هذه العائلة تتميز عن بقية العوائل النباتية الاخرى بتكوين علاقة تكافلية مع البكتريا الـ Rhizobium المتواجدة في المحيط الجذري لها والمعروفة بيكتريا Rhizobia إذ ينتج من هذه العلاقة تكوين عقد جذرية وتثبيت النتروجين الجوي وتحويله إلى امونيا يمكن للنباتات الاستفادة منه/2]. تضم عائلة بكتريا Rhizobiaceae الأجناس التالية: Rhizobium و Azorhizobium و Bradyrhizobium و Sinorhizobium و Mesorhizobium وقسعت إلى مجموعتين الاولى بطيئة النمو 
Journal of Education and Science (ISSN 1812-125X), Vol: 30, No: 3, 2021 (117-132)

Special Issue for Proceeding of $3^{\text {rd }}$ National (1 $1^{\text {st }}$ international conference of biology) (ICBSUM 2021) 5, 6 July

College of Education for Pure Science, University of Mosul, Mosul, Iraq.

Fast Growing Rhizobium التي تتراوح مدة نموها بين سبعة أيام أو اكثر والثانية سريعة النمو Slow Growing Rhizobium التي تستغرق فترة نموها ثلاثة أيام [3].

وتهدف الدراسة الحالية لتشخيص ودراسة الاختلاف الوراثي مابين عزلات بكتيربا الرايزوبيوم المعزولة من جذور النباتات

البقولية المزروعة في بعض مناطق محافظة نينوى باستخدام تقنية مؤشرات التضاعف العشوائي (RAPD-PCR) .

مواد وطرق البحث

1.2 عزل بكتيريا الرايزوبيوم من العقد الجذرية

عزلت بكتيريا الرايزوبيوم من العقد المتكونة على جذور النباتات البقولية المزروعة في اربعة مواقع من محافظة نينوى ( وهي البيت السلكي التابع لقسم علوم الحياة وكذلك المزرعة الموجودة في سادة وبعويزة ومنطقة بعشيقة بالاضافة الى منطقة الرشيدية) ورمزت المناطق بالارقام (4,3,2,1) وبحسب المناطق التي اخذت منها العينات على التوالي، ولستة انواع من نباتات العائلة البقولية (الجت والعدس والحلبة والباقلاء والحمص الترمس)، فصلت العقد المتكونة على جذور النباتات البقولية وغسلت بالماء المقطر . غمرت بعدها في الكحول الاثيلي تركيزه 70\% لمدة ثلاث دقائق بعد ذلك تم غسلها بالماء المقطر المعقم ثلاث مرات ثم نقلت الى محلول هايبوكلورايت الصوديوم NaOCl تركيزه (3:1 حجم /حجم) ماء/هايبوكلورايت الصوديوم وغمرت فيه لمدة 15 دقيقة ثم غسلت بالماء المقطر المعقم وبمعدل ثلاث مرات وبعد ذلك نقلت الى طبق بتري يحتوي على ورق ترشيح معقم لغرض تجفيف العقد من الماء العالق بها بعد ذلك نقلت العقد الى وسط خلاصة الخميرة والمانيتول الصلب Yeast Extract Mannitol Agar (YEMA) وحضنت عند درجة حرارة

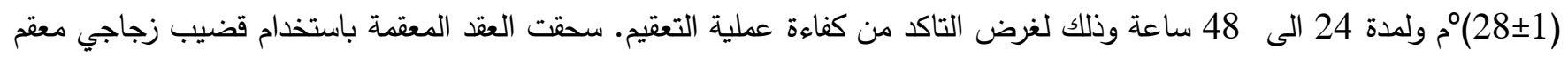
وفرشت بالتخطيط على اطباق بتري معقمة تحتوي على وسط YEMAوحضنت عند درجة حرارة (128 (28 ) م ولمدة 24 الى 48 ساعة. درست اشكال الخلايا البكتيرية ونوع المستعرات باتباع الطرق المعتمدة [4 و5]. كما اجري اختبار التخصص العائلي لكل عزلة حسب طريقة Singh وجماعته [6] وتم التأكد من مقدرة كل عزلة على تكوين العقد الجذرية على المضيف النباتي الخاص بها [7]. 2.2 تشخيص بكتريا الريزوبيوم

Gram stain kit أخذت عينات من المستعمرات النامية ودرست اشكالها واشكال خلاياها وصفاتها المظهرية باستخدام صبغة كرام وفحصت بالعدسة الزيتية (100x) للمجهر الضوئي المركب [5]. 3.2 الاختبارات البايوكيميائية لعزلات بكتيريا الرايزوبيوم شملت الاختبارات البايوكيميائية على السلالات البكتيرية المعزولة من العقد الجذرية لعدد من النباتات البقولية قيد الدراسة، كل من اختبار تسييل الجيلاتين Gelatin liquefaction Test [7]، مقدرة الفلورة Fluorescence Test واختبار انتاجها لانزيم اليوريز

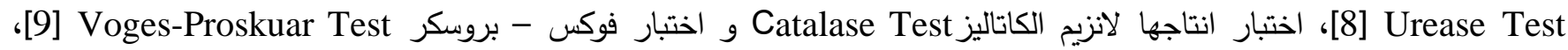
اختبار استهلاكها للسترات Citrate Utilization Test و اختبار انتاج الاندول Indol Production Test [10]، الكثف عن مقدرة 
البكتيريا على انتاج انزيم الاوكسيديز من خلا اختبار Cytochrome Oxidase Test [11]، اختبار المثيل الاحمر Methyl Red

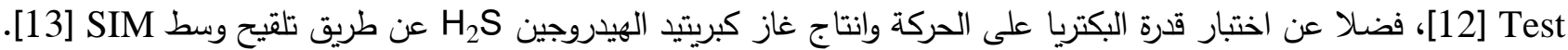

4.2 عزل وتنقية محتوى الـ DNA البلازميدي من عزلات بكتيريا الـ Rhizobium باستخدام المواد المجهزة من قبل شركة

\section{:Promega}

تم عزل محتوى الـ DNA البلازميدي باستخدام عدة العمل الجاهزة المجزة من قبل شركة Promega, اذ رسبت الخلايا البكتيرية للمزرعة البكتيرية السائلة بعمر 48 ساعة باستخدام انبوب طرد مركزي (ابندورف) بحجم 1.5مل باستخدام جهاز الطرد

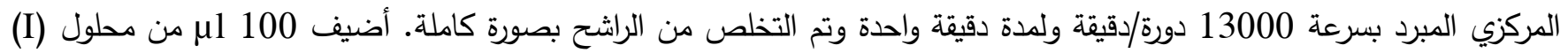
وعلق الراسب باستخدام جهاز المزج Vortex، ثم أضيف اليه 200 من محلول (II)، مزجت الانابيب عن طريق تقليبها بهدوء عدة مرات. اضيف اليها 150 1 150 من محلول (III) ومزج بشكل مباشر عدة مرات كما موضح في الخطوة السابقة، اعيدت عملية الطرد المركزي المبرد لمدة 10 دقائق وبسرعة 13000 دورة/دقيقة. نقل 400 ب من الراشح الى انبوبة طرد مركزي جديدة بحجم 1.5 مل وأضيف إلى الراشح 0.8 مل من كحول الايثانول 95\% ومزج عن طريق تقليب الانابيب ومن ثم ترك بدرجة حرارة الغرفة لمدة خمسة دقائق.أجريت عملية الطرد المركزي وبسرعة قصوى 13000 دورة/ دقيقة ، لمدة 10دقائق وبعدها تم التخلص من الراشح المتكون من الايثانول، وغسل الراسب باستخدام 200 ما من كحول الايثانول 70\% ومزج بلطف ثم تم طردها مركزيا لمدة 5 دقائق للتخلص من الايثانول. بعد ذلك جفت الانابيب بوضعها بصورة مقلوبة على ورق ترشيح للتخلص من بقايا الايثانول، علق الراسب الذي يمثل البلازميدات باستخدام 50 ب1 من محلول TE وحفظ لحين الاستخدام. 5.2 عزل وتنقية الـDNA الجينومي من عزلات بكتربا الرايزوبيا:

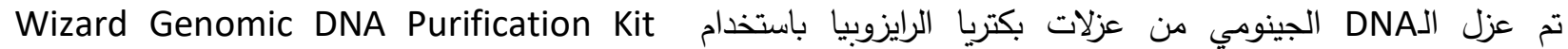

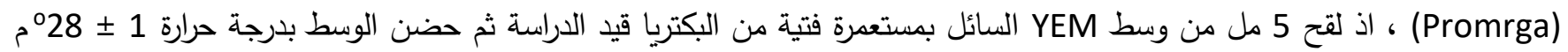
ولمدة 24 ساعة في الحاضنة الهزازة وبسرعة 150 دورة /دقيقة. اخذ 1مل من المزرعة البكتيرية النامية واجري عليها عملية الطرد المركزي بسرعة 13000 دورة \دقيقة ولمدة 5 دقائق وبدرجة حرارة 4 م. سكب الراشح وعلق الراسب البكتيري بحوالي 600 اب من

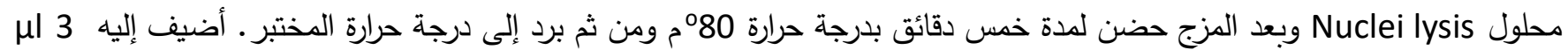
من محلول إنزيم RNase وبعد المزج حضن بدرجة حرارة 370م ولمدة 15 إلى 60 دقيقة ثم برد المزيج إلى درجة حرارة المختبر. أضيف 200 الر من محلول ترسيب البروتين (Protein precipitation solution) إلى المزيج وبعد تحريكه حضن بحمام ثلجي لمدة خمس دقائق أعقبه عملية النبذ المركزي بسرعة 13000 دورة /دقيقة ولمدة 3 دقائق وبدرجة حرارة 4 م. نقل الراشح إلى أنبوبة نظيفة ومعقدة حاوية على 600 من الكحول الايزوبروبانول وبعد المزج أجريت عملية النبذ المركزي وبنفس الظروف السابقة. سكب الراشح وأضيف اليه 600 من 70\% ايثانول وبدرجة حرارة المختبر وبعد التحريك أجريت عملية الطرد المركزي وبنفس Rehydration الظروف أعلاه. جفف الراسب بمدة لا تقل عن 10 إلى 15 دقيقة وعلق الراسب بـ 100 من محلول وحفظ عند درجة حرارة 4 م لحين الاستخدام. (Rehydration solution) 
اخذ 20 مايكروليتر من نماذج الـDNA المحضرة وأكمل الحجم إلى 2 مل بالمحلول المنظم TE-buffer وقيست الكثافة

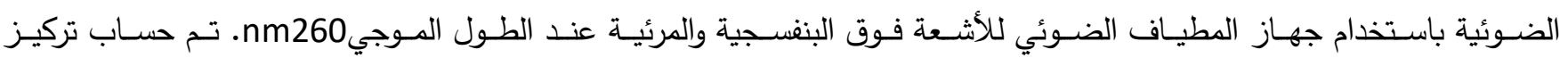
• [الجينومي استناداً إلى[14DNA 7.2 ظروف تفاعل التضخيم لنماذج الـ DNAالجينومي المحضرة: استخدم الـ DNA المحضر من العزلات قيد الدراسة لأجراء تفاعلات مؤشرات التضاعف العشوائي وباستخدام البوادئ (1) كما في الجدول (AlphaDNA)

الجدول(1) البادئات العشوائية المستخدمة في تفاعل RAPD-PCR

\begin{tabular}{|c|c|c|}
\hline تسلسل القواعد النتروجينية & البادئ & ت \\
\hline $5^{5} G_{G T G C G G G A A^{3 \prime}}$ & OPF-01 & 1 \\
\hline 5'GTTTCGCTCC ${ }^{3}$ & OPR-01 & 2 \\
\hline $5^{\prime} \mathrm{CGGCCCTGT}^{3^{\prime}}$ & OPR-02 & 3 \\
\hline${ }^{5} \mathrm{AAGAGCCCGT}^{3^{\prime}}$ & OPR-03 & 4 \\
\hline
\end{tabular}

أجريت التفاعلات باستخدام إثنا عشر انبوبا من الانابيب الحاوية على PCR PreMix (Bioneer) Kit مقسمة على ست

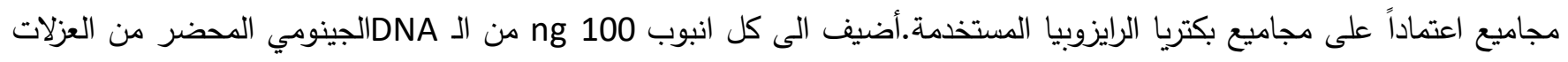

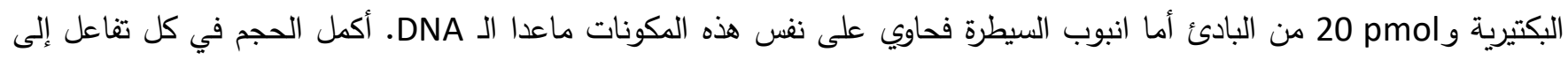

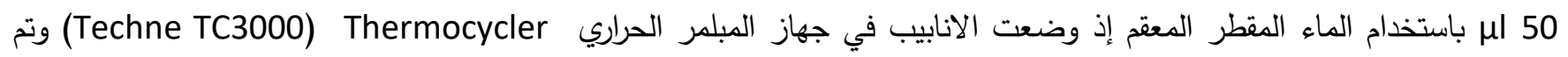
برمجة الجهاز حسب طريقة [15]، واستخدم في البرنامج 35 دورة (مسخ الـ DNA بدرجة حرارة 94 م ولمدة دقيقة واحدة، ارتباط

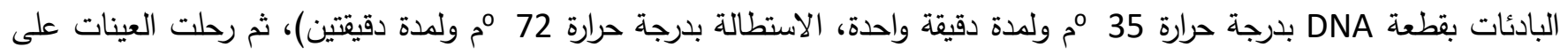

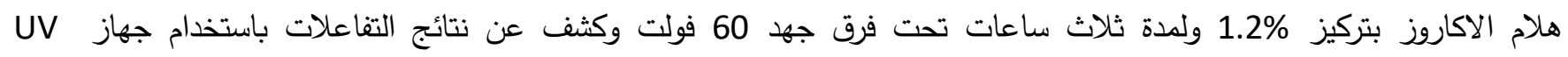
Transilluminator 8.2 تحليل نتائج التضاعف العشوائي لا DNA(RAPD-PCR):

اخذت النتائج الظاهرة على هلام الاكاروز وكتبت بثكل جدول توصيفي لبيان العلاقة ما بين العزلات حيث يمثل الرقم (1) وجود الحزمة بينما الرقم (0) لعدم وجودها. عين المجموع الكلي للحزم مع حجمها والمتولدة من قبل كل بادئ ولكل عزلة ابتاء من الحزم ذات الأحجام الصغيرة والموجودة في أسفل الهلام وصولاً إلى الأعلى حيث الحزم الأكبر حجماً. 
تم حساب قيمة كفاءة كل بادئ والقوة التميزية له حيث يستفاد منها في تحديد التسلسلات المتممة للبادئ في المادة الوراثية لكل عزلة وذلك باستخدام صيخ رياضية معتمدة [16]، وجدت العلاقة الوراثية بين العزلات البكتيرية المنتخبة بتحويل بيانات التوصيف Similarity for Qualitative Data باستخدام الحاسوب ضمن برنامج) (Distance) (إلى قيم المسافة (Characterization data) الذي يعتمد على معادلة [15IMQUL)

رسم المخطط الثجريDDendrogram الذي يوضح العلاقة الوراثية بين بكتريا الرايزوبيا المعزولة من العقد الجذرية للنباتات البقولية المدروسة والذي يعتمد قيم الأبعاد الوراثية التي تم الحصول عليها من الخطوة السابقة وذلك عن طريق استخدام البرنامج Un weighted Pair-Group Method with Arithmetic Averages (UPGMA) إإذ تم إدخال هذه القيم عن طريق الحاسوب ضمن برنامج MVPP النسخة 3.22 واستخدم تحليل Jaccard's Coefficient في تحليل النتائج التي تم الحصول عليها من خلا استخدام البرنامج المذكور أعلاه. : 9.2

اعتمد طريقة Kado و [iu [17 في تحضير هلام الاكاروز وترحيله كهربائياً. حملت العينات باستخدام صبغة التحميل إلى البر20 من عينات الـDNA البلازميدي وعينة من المقطوعة بالإنزيم القاطع EcoRI كعليمة قياسية لتقدير حجم الحزم في هلام الاكاروز • حملت هذه العينات في حفر هلام الاكاروز استخدم فرق جهد 45 فولت لمدة 15 دقيقة بعد ذلك تم زيادة الفولتية إلى 70 فولت ولمدة ثلاث ساعات. صبغ الهلام بصبغة بروميد الاثيديومEthidium bromide وبتركيز 1 ولمدة 15 ولمدة إلى 30 دقيقة ثم

عرض للأشعة فوق البنفجية عند الطول الموجي (nm254 ) في جهاز للكثف عن حزم الـ UV Transilluminator للـ DNA البلازميدي في العينات قيد الاختبار •

3. 3. النتائج والمناقشة: 1.3 اختبار التخصص العائلي لبكتربا الريزوبيا المعزولة:

لوحظ بدء تشوه الثعيرات الجذرية للنباتات البقولية بعد ثلاثة إلى خمسة ايام من التحضين مكونة اشكال ملتوية أو ملتفة تعرف

$$
\text { (بعصا الراعي) ومن ثم تكوين العقد الاولية والناضجة بعد مرور } 10 \text { إلى } 21 \text { يوم من الاصلية. }
$$

ظهرت في نباتي الجت والحلبة ذات شكل متطاول إذ بلغ معدل عدد العقد 3 لكل نبات موزعة على المحور الرئيس والتقرعات

الثانوية والملقحة ببكتربا RhM و RhT على التوالي. بينما كان معدل عدد العقد الناتجة 4 عقد ذات شكل منتظم (كروي) والمتكونة على جذور نباتات الحمص والباقلاء والعدس والملقحة ببكتريا الرايزوبيا RhC و RhF و RhL على التوالي، في حين تكونت ثلاث عقد جذرية ذات اشكال متطاولة على جذور نباتات الترمس والملقحة ببكتريا الرايزوبيا لمجموعة RhLu ، كما هو واضح قي الاشكال (1- 


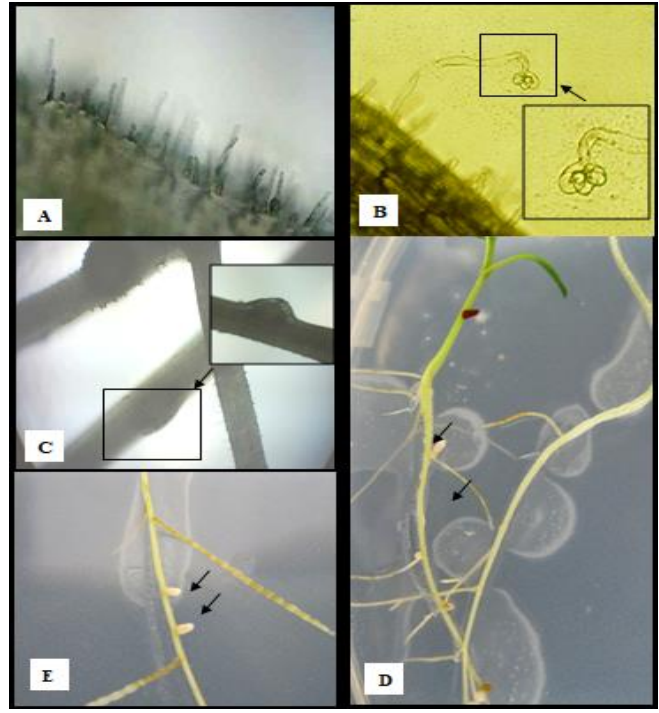

شكل (2) مر احل تكون العقد الجذرية في نبات الحلبة A

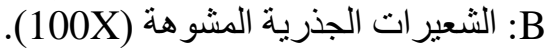

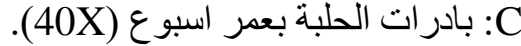
D : العقد الجذرية على الجذر الرئيس لنبات الحلبة. E

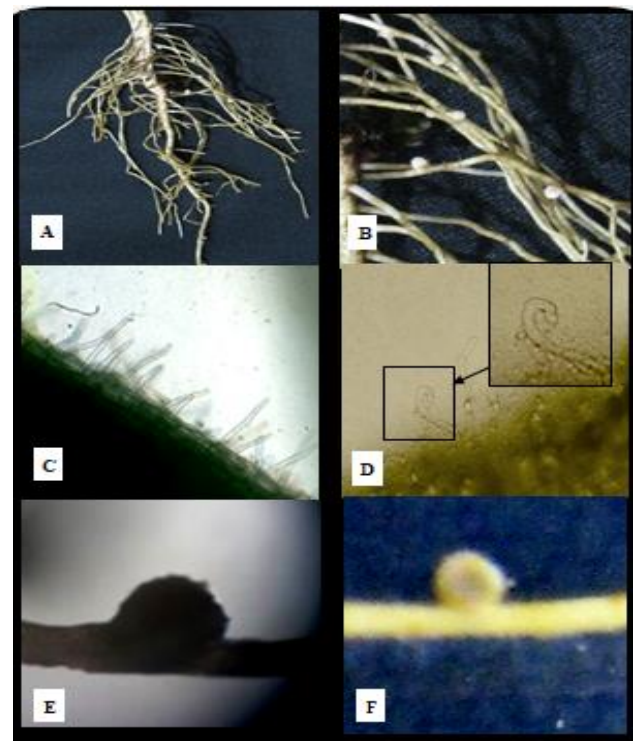

شكل (4) مر احل تكون العقد الجذرية في نبات الباقلاء

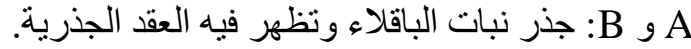
C

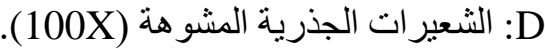
E F

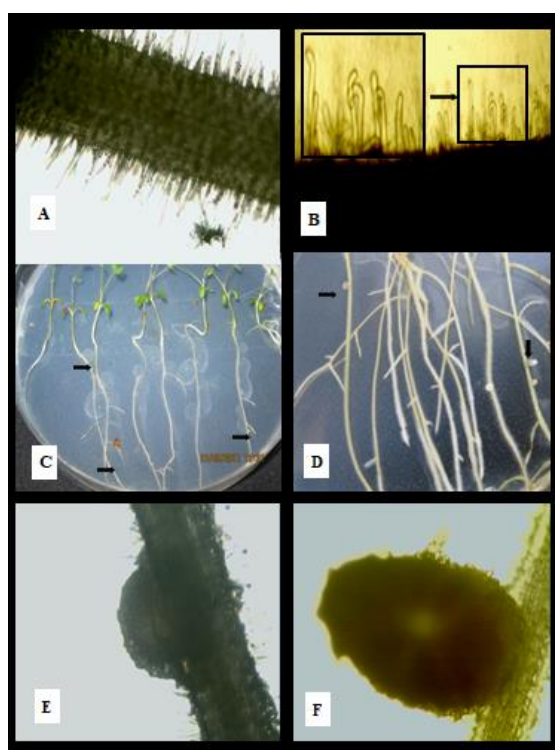

شكل (1) مر احل تكون العقد الجذرية في نبات الجت A الشعيرات الجذرية غير المشوهة (10X) (100X).

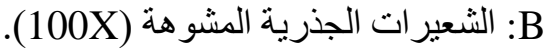

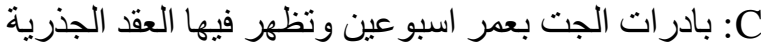
العقد الجذرية المتكونة على الجذر الرئيس لنبات.

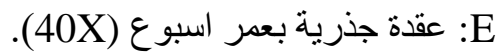
F Fقدة جذرية ناضجة (40X).

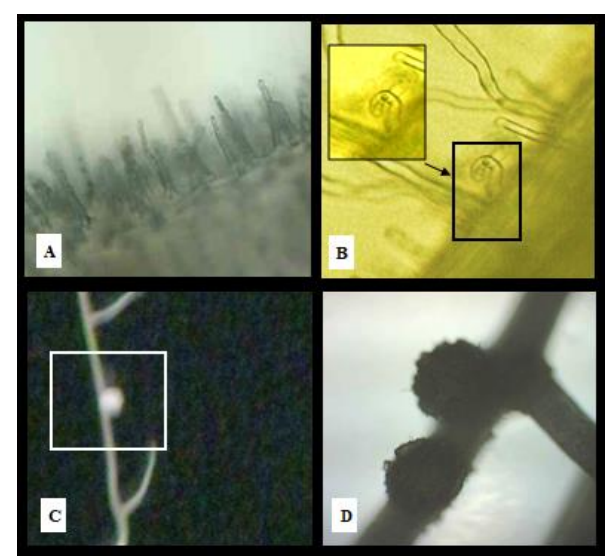

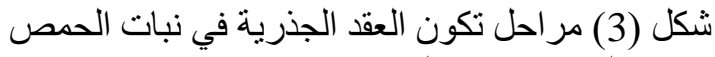

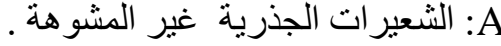

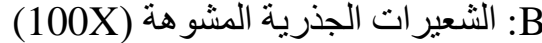

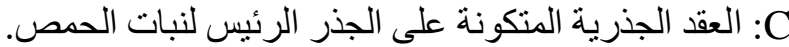

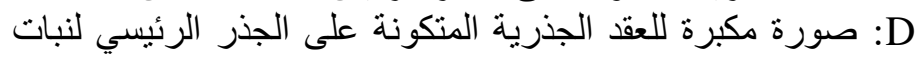
حمص (40X). 


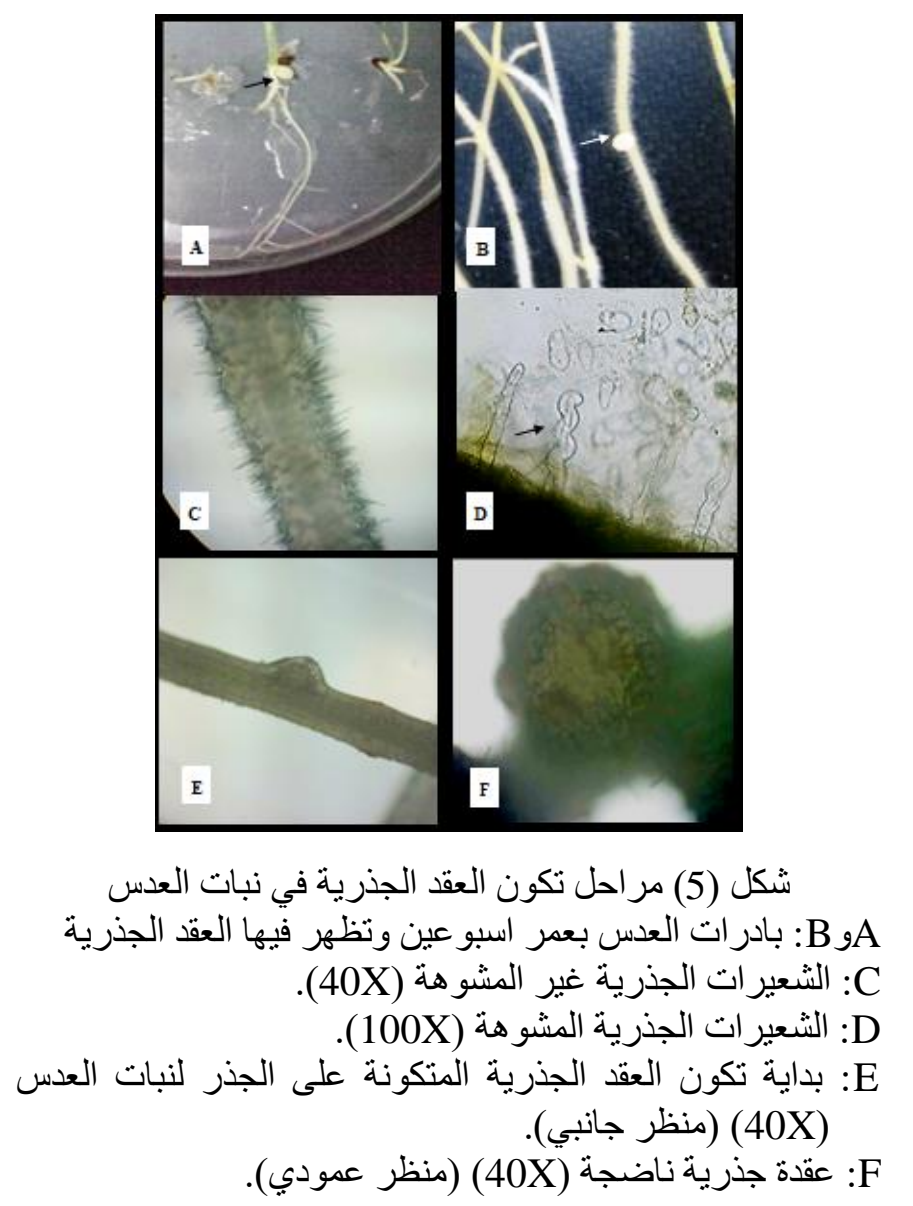

2.3 الصفات المورفولوجية والزرعية لبكتريا الرايزوبيا المعزولة:

أظهرت النتائج أن المستعمرات البكتيرية النامية لجميع العزلات على الاطباق الحاوية على وسط YEM الصلب كانت ذات الوان متباينة (مابين العاجي والكريمي) ودائرية الثكل سطوحها مرتفعة وذات حافات ملساء ومخاطية القوام. كما بينت نتائج صبغ العزلات بصبغة كرام بأنها بكتريا سالبة وذات اشكال مجهرية. هذه الصفات التي تمت ملاحظتها لمجموعتي بكتريا الرايزوبيوم RhM و RhT تثابه تلك التي عزلت من العقد الجذرية لنبات الجت من قبل الباحثين [9]، أما مجاميع بكتريا الرايزوبيوم RhC و RhF و RhL و فظهرت اكثر لزوجة من المجموعتين السابقتين • هذه النتائج تتوافق مع تلك التي وجدها الباحثين [15hLu اصناف من بكتريا الرايزوبيوم المعزولة من نبات العدس، وكذلك ما وجده Gauri وآخرون[18] عند مقارنتهم لحوالي .85 عزلة من بكتريا الرايزوبيا التي كونت عقدا جذرية على نباتات البرسيم دع العزلة القياسية Rhizobium trifolii (MTCC905). 
Journal of Education and Science (ISSN 1812-125X), Vol: 30, No: 3, 2021 (117-132)

Special Issue for Proceeding of $3^{\text {rd }}$ National (15t international conference of biology) (ICBSUM 2021) 5, 6 July

College of Education for Pure Science, University of Mosul, Mosul, Iraq.

:Biochemical Tests 3.3

بينت نتائج الاختبارات البايوكيميائية لعزلات الرايزوبيا المعزولة انها امتازت ببعض الصفات المشتركة مع بعضها (الجدول3)، كقدرتها على الحركة كذلك تلون ورقة الترشيح المشبعة بمحلول كاشف الاوكسيديز باللون البنفجي والدال على قدرة هذه البكتريا لإنتاج انزيم الاوكسيديز • وقدرة البكتريا على إنتاج إنزيم الكاتاليز من خلال تكوين فقاعات الغاز على شريحة الفحص، بينمالظهرت نتيجة سالبة فيما يخص اختبارات الاندول والفوكس بروسكر واستهلاك سترات الصوديوم وعدم قدرتها لى انتاج غاز كبريتيد الهيدروجين وأنزيمي اليوريز والجيلاتينيز [19]، في حين كانت اختبارات إنتاج الحامض من السكريات المانوز والكلوكوز والسيليلوز موجبة من خلال تحليل السكريات وتحويل الوسط إلى الحامضي بدلالة تغير لون الوسط من الأصفر إلى الأخضر ، أما بالنسبة لبقية السكريات الرامنوز S. والمالتوز فقد كانت سالبة. هذه النتائج تتفق مع ما ذكره Shahzad واخرون [20] عند دراستهم لخمسين عزلة من بكتريا meliloti

الجدول(2): الاختبارات البايوكيميائية لعزلات بكتريا الرايزوبيا المعزولة.

\begin{tabular}{|c|c|c|c|c|c|c|c|c|c|c|c|c|c|c|c|c|c|c|c|c|c|c|c|c|}
\hline \multicolumn{4}{|c|}{$\mathrm{RhLu}$} & \multicolumn{4}{|c|}{ RhL } & \multicolumn{4}{|c|}{ RhF } & \multicolumn{4}{|c|}{ RhC } & \multicolumn{4}{|c|}{$\mathrm{RhT}$} & \multicolumn{4}{|c|}{ RhM } & \multirow{2}{*}{ الاختبارات } \\
\hline 4 & 3 & 2 & 1 & 4 & 3 & 2 & 1 & 4 & 3 & 2 & 1 & 4 & 3 & 2 & 1 & 4 & 3 & 2 & 1 & 4 & 3 & 2 & 1 & \\
\hline+ & + & + & + & + & + & + & + & + & + & + & + & + & + & + & + & + & + & + & + & + & + & + & + & المركة \\
\hline 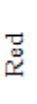 & $\begin{array}{l}\vec{D} \\
\stackrel{\Delta}{\simeq}\end{array}$ & $\begin{array}{l}\vec{D} \\
\stackrel{\Delta}{*}\end{array}$ & 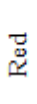 & 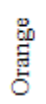 & 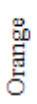 & 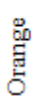 & 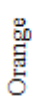 & 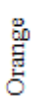 & $\begin{array}{l}\stackrel{\circ}{\circ} \\
\stackrel{\mathbb{E}}{5}\end{array}$ & 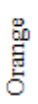 & 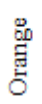 & $\stackrel{\stackrel{D}{\infty}}{\underset{\Xi}{*}}$ & $\begin{array}{l}\stackrel{0}{\circ} \\
\stackrel{\mathbb{J}}{\Xi}\end{array}$ & $\begin{array}{l}\stackrel{0}{0} \\
\stackrel{\mathbb{J}}{\sigma} \\
\end{array}$ & 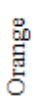 & 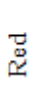 & 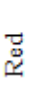 & $\underset{\ddot{\Xi}}{\vec{\beth}}$ & 总 & 兰 & 兑 & 兯 & 兰 & Congo red \\
\hline+ & + & + & + & + & + & + & + & + & + & + & + & + & + & + & + & + & + & + & + & + & + & + & + & oxidase \\
\hline+ & + & + & + & + & + & + & + & + & + & + & + & + & + & + & + & + & + & + & + & + & + & + & + & Catalase \\
\hline- & - & - & - & - & - & - & - & - & - & - & - & - & - & - & - & - & - & - & - & - & - & - & - & Sodium citrate \\
\hline- & - & - & - & - & - & - & - & - & - & - & - & - & - & - & - & - & - & - & - & - & - & - & - & $\mathrm{H}_{2} \mathrm{~S}$ \\
\hline- & - & - & - & - & - & - & - & - & - & - & - & - & - & - & - & - & - & - & - & - & - & - & - & Urea hydrolysis \\
\hline- & - & - & - & - & - & - & - & - & - & - & - & - & - & - & - & - & - & - & - & - & - & - & - & Indol \\
\hline- & - & - & - & - & - & - & - & - & - & - & - & - & - & - & - & - & - & - & - & - & - & - & - & Yoges proskauer \\
\hline- & - & - & - & - & - & - & - & - & - & - & - & - & - & - & - & - & - & - & - & - & - & - & - & Gelatin \\
\hline $\mathrm{R}$ & $\mathrm{R}$ & $\mathrm{R}$ & $\mathrm{R}$ & $\mathrm{R}$ & $\mathrm{R}$ & $\mathrm{R}$ & $\mathrm{R}$ & $\mathrm{W}$ & $\mathrm{W}$ & $\mathrm{W}$ & $\mathrm{W}$ & $\mathrm{R}$ & $\mathrm{R}$ & $\mathrm{R}$ & $\mathrm{R}$ & $\mathrm{R}$ & $\mathrm{R}$ & $\mathrm{R}$ & $\mathrm{R}$ & $\mathrm{R}$ & $\mathrm{R}$ & $\mathrm{R}$ & $\mathrm{R}$ & $2 \%$ \\
\hline $\mathrm{R}$ & $\mathrm{R}$ & $\mathrm{R}$ & $\mathrm{R}$ & $\mathrm{R}$ & $\mathrm{R}$ & $\mathrm{R}$ & $\mathrm{R}$ & $\mathrm{S}$ & $\mathrm{S}$ & $\mathrm{S}$ & $\mathrm{S}$ & $\mathrm{S}$ & $\mathrm{S}$ & $\mathrm{S}$ & $\mathrm{S}$ & $\mathrm{R}$ & $\mathrm{R}$ & $\mathrm{R}$ & $\mathrm{R}$ & $\mathrm{R}$ & $\mathrm{R}$ & $\mathrm{R}$ & $\mathrm{R}$ & Sodium \\
\hline $\mathrm{S}$ & $\mathrm{S}$ & $\mathrm{S}$ & $\mathrm{S}$ & $\mathrm{W}$ & $\mathrm{W}$ & $\mathrm{W}$ & W & $\mathrm{S}$ & $\mathrm{S}$ & $\mathrm{S}$ & $\mathrm{S}$ & $\mathrm{S}$ & $\mathrm{S}$ & $\mathrm{S}$ & $\mathrm{S}$ & $\mathrm{R}$ & $\mathrm{R}$ & $\mathrm{R}$ & $\mathrm{R}$ & $\mathrm{R}$ & $\mathrm{R}$ & $\mathrm{R}$ & $\mathrm{R}$ & Chloride \\
\hline $\mathrm{S}$ & $\mathrm{S}$ & $\mathrm{S}$ & S & $\mathrm{S}$ & $\mathrm{S}$ & $\mathrm{S}$ & $\mathrm{S}$ & $\mathrm{S}$ & $\mathrm{S}$ & $\mathrm{S}$ & $\mathrm{S}$ & $\mathrm{S}$ & $\mathrm{S}$ & S & $\mathrm{S}$ & $\mathrm{W}$ & W & $\mathrm{W}$ & $\mathrm{W}$ & $\mathrm{W}$ & $\mathrm{W}$ & $\mathrm{W}$ & $\mathrm{W}$ & Tolerance \\
\hline $\mathrm{Y}$ & $\mathrm{Y}$ & $\mathrm{Y}$ & $\mathrm{Y}$ & $\mathrm{Y}$ & $\mathrm{Y}$ & $\mathrm{Y}$ & $\mathrm{Y}$ & B & B & B & B & $\mathrm{Y}$ & $\mathrm{Y}$ & $\mathrm{Y}$ & $\mathrm{Y}$ & $\mathrm{Y}$ & $\mathrm{Y}$ & $\mathrm{Y}$ & $\mathrm{Y}$ & $\mathrm{Y}$ & $\mathrm{Y}$ & $\mathrm{Y}$ & $\mathrm{Y}$ & Brome thvmol blue \\
\hline+ & + & + & + & + & + & + & + & + & + & + & + & + & + & + & + & + & + & + & + & - & - & - & - & Acid from msaltose \\
\hline+ & + & + & + & + & + & + & + & + & + & + & + & + & + & + & + & - & - & - & - & + & + & + & + & Acid from mannose \\
\hline+ & + & + & + & + & + & + & + & & & + & & + & + & + & + & - & - & - & + & + & + & + & + & Acid from Glucose \\
\hline+ & + & + & + & + & + & + & + & + & + & + & + & + & + & + & + & + & + & + & + & + & + & + & + & Acid from rhamnose \\
\hline+ & + & + & + & + & + & + & + & + & + & + & + & + & + & + & + & + & + & + & + & + & + & + & + & Acid from Cellulose \\
\hline+ & + & + & + & + & + & + & + & - & - & - & - & - & - & - & - & + & + & + & + & + & + & + & + & Fluoresce \\
\hline
\end{tabular}

كنلك يظهر من الجدول (2) تبايناً في لون المستعمرات عند زراعة بكتريا الرايزوبيا على وسط YEM الصلب الحاوي على 0025\% من صبغة الـ Congo Red (CR) حيث ظهرت مستعمرات مجموعة RhM باللون الوردي الفاتح والمعزولة من العقد الجذرية لنباتات الجت في حين كان اللون احمراً مميزاً لمجاميع RhT و RhLu والتي عزلت من العقد الجذرية لنباتات الحلبة والترمس على التوالي أما بقية مجاميع بكتريا الرايزوبيا ذات اللون البرتقالي والمتمثلة بالهجاميع RhC و RhF و RhL والدعزولة من العقد الجذرية لنباتات الحمص والباقلاء و العدس على الثكل (6). 
إن ظهور المستعمرات بهذه الألوان يذل على قابلية هذه البكتريا على التقاط هذه الصبغة من الوسط وبدرجات مختلفة، هذه الصبغة تلون Cellulose و و amyloid وتتداخل مع D-glucan ومن المحتمل ان ترتبط هذه الصبغة مع السكريات المتعددة الموجودة

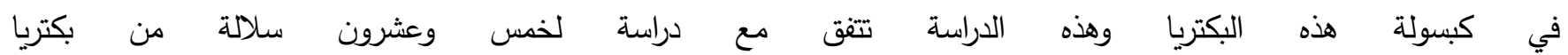
R. leguminosarum الصبغة كعليمة للسلالة في تشخيص R. leguminosarum. هذا التباين بدا مشابهاً في سلالات بكتريا Re trifoli. التي نميت على اوساط YMA الحاوية على صبغة (CR) وبدرجة حرارة 24-28 مج [22,21].

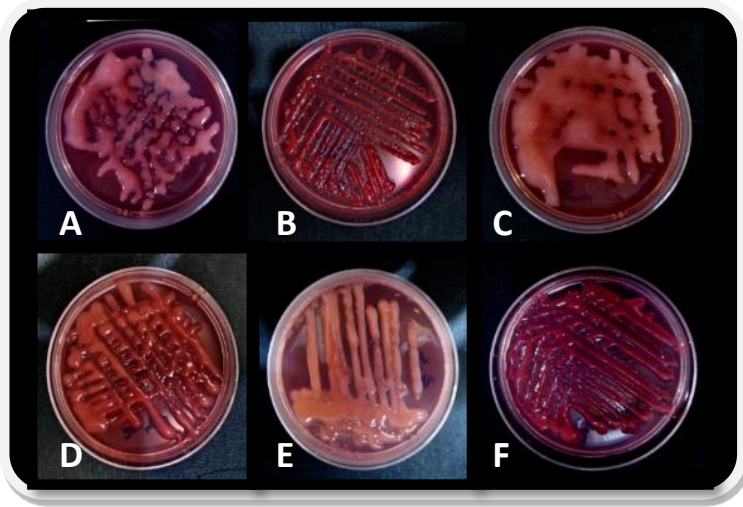

Congo red الشكل (6) اختبار قابلية بكتربا الرايزوبيا والمعزولة من العقد الجذربة للنباتات البقولية قيد الدراسة على التقاط صبغة

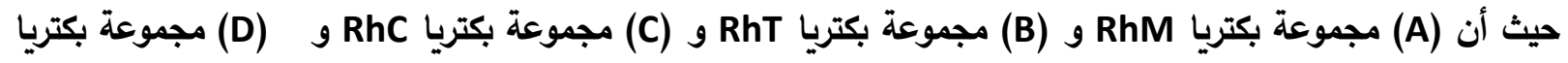

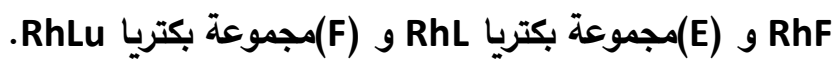
كذلك أظهرت النتائج أن هذه المجاميع تتحمل تحملاً متبايناً لتراكيز من كلوريد الصوديوم (NaCl)، اذ أظهرت العزلات في المجاميع البكتيرية RhM و RhT والمعزولة من العقد الجذرية لنباتات الجت والحلبة على التوالي نمواً جيداً عند زراعتها على وسط YEM الحاوي على التراكيز 2 و 4 و6 \% من كلوريد الصوديوم في حين فثلت في النمو عند تركيز 8 \% منه. اما البكتريا المعزولة من العقد الجذرية لنباتات الحمص والباقلاء ضمن المجموعتين RhC و RhF على التوالي فقد تفاوتت في نموها إذ كان جيداً للبكتريا ضمن المجموعة RhC عند التركيز \% 2\% بينما كانت البكتريا ضمن المجموعة RhF ضعيفة النمو عند نفس التركيز وفثلت كلا المجموعتين في تحملها للتراكيز 4 و 6 و 8 \% من كلوريد الصوديوم. اما مجموعة بكتريا RhL و RhLu والمعزولتين من العقد الجذرية لنباتات العدس والترمس على التوالي فقد أظهرت كلاهما نمواً جيد عند التركيزين 2 و 4 \% وفثلت بكتريا المجموعة الاولى من النمو عند التركيز6\% بينما كان النمو للمجموعة الثانية ضعيفاً عند التركيز 6 \% بينما لم تظهر كلا المجموعتين اي تحمل لكلوريد الصوديوم عند التركيز 8\%. وقد يعزى سبب ذلك عندما تصادف البكتريا بيئة مختلفة مثل ارتفاع درجة الحرارة ووجود المعادن الثقيلة والاملاح ومستوى محدد من التغذية عندئذ تبدأ البكتيريا ببرنامج التعبير الجيني كاستجابة للجهد الازموزي بواسطة تركيز عالي من الاملاح والذي يظهر مجموعة من البروتينات تتتج بكميات متزايدة استجابة إلى هذا الجهد ، كما وتعد صفة المقاومة للملوحة من الصفات التثخيص المهمة و قد تختلف صفة التحمل لأملاح كلوريد الصوديوم باختلاف المناطق المعزولة منها البكتريا [20,19]. 
Journal of Education and Science (ISSN 1812-125X), Vol: 30, No: 3, 2021 (117-132)

Special Issue for Proceeding of $3^{\text {rd }}$ National (1 $1^{\text {st }}$ international conference of biology) (ICBSUM 2021) 5, 6 July College of Education for Pure Science, University of Mosul, Mosul, Iraq.

في بكتريا R. etli EBRI26 فان البروتينات الدذابة والمعزولة منها والتي فصلت بواسطة الترحيل الكهربائي للهلام وتم ملاحظتها بعد صبغ الهلام بصبغة كومزي تبين ان هناك تعبيراً لستة من البروتينات على الاقل باوزان جزيئية مختلفة قد تم ملاحظتها بعد تعرض البكتريا إلى 4 من كلوريد الصوديوم مقارنة بنف السلالة والمنماة في وسط خالي من الاملاح. في تجربة اخرى فان البروتينات الدذابة في المزارع البكتيرية المحفزة وغير المحفزة بالاملاح للسلالة R. etli EBRI26 قد تم تاشيرها منفصلةً بصبغات السيانو التألقية قبل عملية الترحيل الكهبائي وقد لوحظ أن هناك 49 بروتيناً قد تم التعبير عنها بصورة مميزة بعد اضافة كلوريد الصوديوم وان 14 بروتيناً منها كان بمستوى عالي من التعبير و 35 منها بتعبير واطئ [23]. إن مجاميع بكتريا الرايزوبيا RhM و RhT و RhC و RhL و RhLu والمعزولة من العقد الجذرية للنباتات قيد الدراسة على وسط YEM الصلب والحاوي على 0.0025 \% من صبغة Bromothymol blue تبين انها غيرت لون الوسط من اللون الازرق إلى الاصفر وذلك بسبب تغييرها لقيمة الاس الهيدروجيني إلى الحامضي باستثناء بكتريا من مجموعة RhF التي عزلت من العقد الجذرية لنباتات الباقلاء فإنّ الوسط بقي محتفظا باللون الازرق. عند زراعة بكتريا الرايزوبيوم المعزولة على وسط King media فانها اظهرت

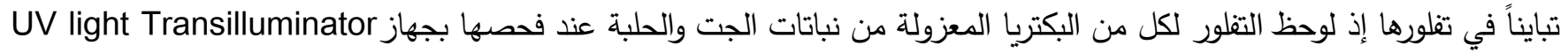

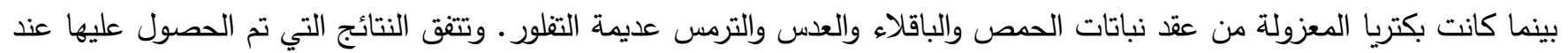
دراسة عشرين عزلة بكتيرية معزولة من العقد الجذرية لنباتات الفول من منطقة sanliurfa التركية اذ تمكنوا من تصنيفها إلى ثلاث مجاميع على اساس تحملها لتراكيز مختلفة من كلوريد الصوديوم، تمكنت المجموعة الاولى من النمو على الاوساط الغذائية الحاوية على او2 و 3 و4 \% من كلوريد الصوديوم بينما المجموعة الثانية لم تتمو على التركيز 4\% منه في حين كانت المجموعة الاخيرة ضعيفة النمو اذ استطاعت النمو على التركيزين 1 و 2\%من كلوريد الصوديوم [24].

4.3 تقانة التفاعل التضاعفي متعدد الاشكال لسلسلة الـRAPD - PCR) DNA): تم قياس قيم تراكيز الـDA ونقاوته الجدول (3) المحضرة من كل عزلة باستخدام جهاز المطياف الضوئي للأشعة فوق

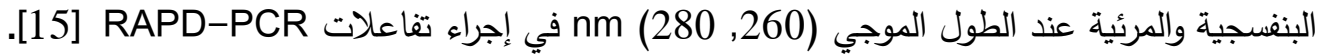

RAPD - PCR. الجدول (3) تراكيز ونقاوة الـDNA المنقاة من عزلات بكتريا الريزوبيا والمستخدمة في تفاعل

\begin{tabular}{|c|c|c|c|}
\hline التركيز العزلة البكتيرية| & $(\boldsymbol{\mu g} / \mathbf{m l}$ & $ت$ \\
\hline 1.657 & 0.169 & $\mathrm{M} 1$ & 1 \\
\hline 1.712 & 0.170 & $\mathrm{M} 2$ & 2 \\
\hline 1.612 & 0.261 & $\mathrm{~T} 1$ & 3 \\
\hline 1.625 & 0.254 & $\mathrm{~T} 2$ & 4 \\
\hline 1.715 & 0.138 & $\mathrm{C} 1$ & 5 \\
\hline 1.604 & 0.140 & $\mathrm{C} 2$ & 6 \\
\hline 1.620 & 0.210 & $\mathrm{~F} 1$ & 7 \\
\hline 1.548 & 0.190 & $\mathrm{~F} 2$ & 8 \\
\hline 1.524 & 0.167 & $\mathrm{~L} 1$ & 9 \\
\hline 1.584 & 0.241 & $\mathrm{~L} 2$ & 10 \\
\hline 1.658 & 0.295 & $\mathrm{Lu} 1$ & 11 \\
\hline 1.724 & 0.275 & $\mathrm{Lu} 2$ & 12 \\
\hline
\end{tabular}


Journal of Education and Science (ISSN 1812-125X), Vol: 30, No: 3, 2021 (117-132)

Special Issue for Proceeding of $3^{\text {rd }}$ National (1 $1^{\text {st }}$ international conference of biology) (ICBSUM 2021) 5, 6 July College of Education for Pure Science, University of Mosul, Mosul, Iraq.

RAPD-PCR البادئات المستخدمة في تفاعلات الـ 5.3

استخدم البادئ F1 والحاوي على عشر قواعد نتروجينية ذاتالتسلسل '5'GGTGCGGGAA3 وتحت ظروف التفاعل أظهرت

النتائج ظهور 23 مجموعة من حزم الـDNA المتباينة في الحجم والمتولدة من التفاعل والتي توزعت على 12 عزلة من بكتريا الرايزوبيا وتراوحت احجامها مابين (100 إلى 2000) زوج (الجدول7 ). بلغ اعلى عدد من حزم الـDNA المتولدة من التفاعل ، تسع حزم لنبات العدس، بينما لم يتم الحصول على حزم من الDNA لبكتريا الرايزوبيوم المعزولة من العقد الجذرية لنبات الحمص وربما يعود البسبب إلى عدم وجود تسلسلات من القواعد النتروجينية في الـ DNA الجينومي والتي يمكن ان يرتبط بها مع البادئ F1، بلغت كفاءة البادئ المستخدم 30.62 بينما كانت القوة التمييزية لهذا البادئ 31.08 (الجدول 4).

الجدول (4) أعداد حزم الـ DNA الكلية وإلمتباينة المتولدة من استخدام البوادئ F1 و R1 و R2 و R3 في تفاعلات R2 وكذلك الكفاءة والقوة التمييزية لكل منها.

\begin{tabular}{|c|c|c|c|c|c|c|}
\hline قوة التمييز & كفاءة البادئ & عداد الحزمج & عدد الحزم & تسلسل القواعد & اسم البادئ & ت \\
\hline 32.20 & 30.10 & 19 & 65 & ${ }^{5^{\prime}}$ GGTGCGGGAA & OPF-01 & 1 \\
\hline 30.50 & 22.86 & 18 & 48 & ${ }^{5}$ GTTTCGCTCC ${ }^{3}$ & OPR-01 & 2 \\
\hline 27.12 & 34.76 & 16 & 73 & 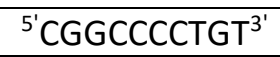 & OPR-02 & 3 \\
\hline 10.17 & 11.43 & 6 & 24 & ${ }^{5}$ AAGAGCCCGT ${ }^{3 \prime}$ & OPR-03 & 4 \\
\hline & & 59 & 210 & & \multicolumn{2}{|c|}{ العدد الكلي } \\
\hline
\end{tabular}

التحليل الاحصائي

تم تحويل نتائج الهجرة الكهربائية في هلام الاكاروز (الثكل 7) بتركيز 1.2\% لنواتج تفاعلات التضاعف العشوائي الـDNA الجينومي المنقاة من بكتريا الرايزوبيا إلى جدول توصيفي لحزم الـDNA الجينومي حيث وجدت علاقة معدلات المسافة الوراثية عن طريق تكوين مصفوفة Distance matrix باستخدام تحليل Average Distance (الجدول 6). 


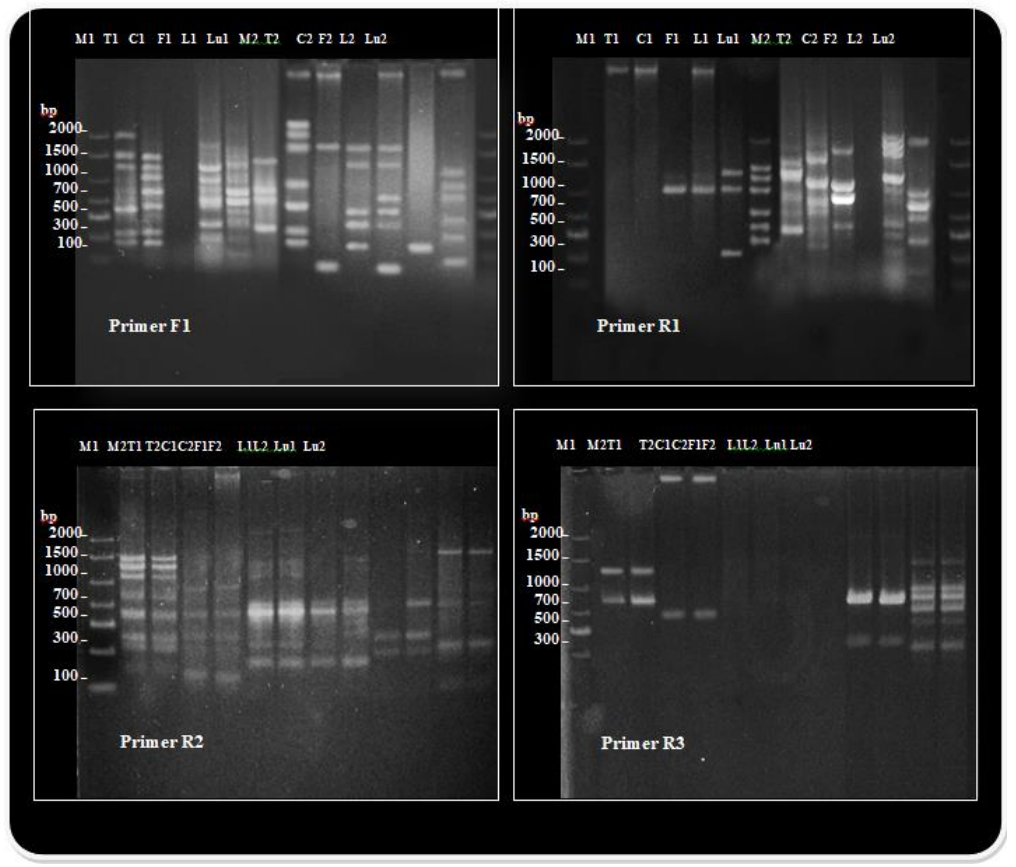

الثكل (7) الترحيل الكهربائي في هلام الاكاروز (1.2\%) لنواتج تفاعلات التضاعف العشوائي للاDNA الجينومي المنقى من بكتريا الريزوبيوم المعزولة من العقد الجذرية للنباتات البقولية: الجت (الاعمدة M1 و M2) و الحلبة (T1 و T2) و الحمص (C1) و و C2 الباقلاء (F1 و F2) و العدس (L1 و L2) و الترمس (Lu1 و Lu2) باستخدام البادئات F1 و R1 و R2 و R3. يتبين من المصفوفة اعلاه أن اطول مسافة وراثية هي 0.791 والتي تفصل ما بين انواع من بكتيريا الرايزوبيا والمعزولة من العقد الجذرية لنباتات الجت والباقلاء وكذلك الحلبة والترمس والحمص والمزروعة في ناحية بعثيقة والحلبة والعدس في منطقتي الدراسة. بينما كانت اقصر مسافة وراثية ما بين الانواع البكتيرية هي 0.408 وتثمل تلك المعزولة من العقد الجذرية لنباتات الجت والحلبة والمزروعة في البيت السلكي و الجت في منطقتي الدراسة. اما بقية المسافات الوراثية فكانت ما بين قيم المسافات المذكورة اعلاه. من الملاحظ فان الانواع من بكتيريا الرايزويا المعزولة من العقد الجذرية لنفس المضيف تتفصل عن بعضها البعض بمسافات أقصر من تلك المسافات بين الانواع البكتيرية المعزولة من العقد الجذرية لمضايف مختلفة، ومن الملاحظ ايضاً ان هناك تباينا وراثيا مابين العزلات البكتيرية ضمن النوع الواحد والمعزولة من العقد الجذرية للنباتات البقولية المزروعة في مناطق مختلفة. 
الجدول (6) قيم مصفوفة المسافات الوراثية ما بين أنواع بكتربا الرايزوبيوم والمعزولة من العقد الجذربية للنباتات البقولية كما

$$
\text { استخرجت من مؤشرات تفاعلات التضاعف العثوائي لها. }
$$

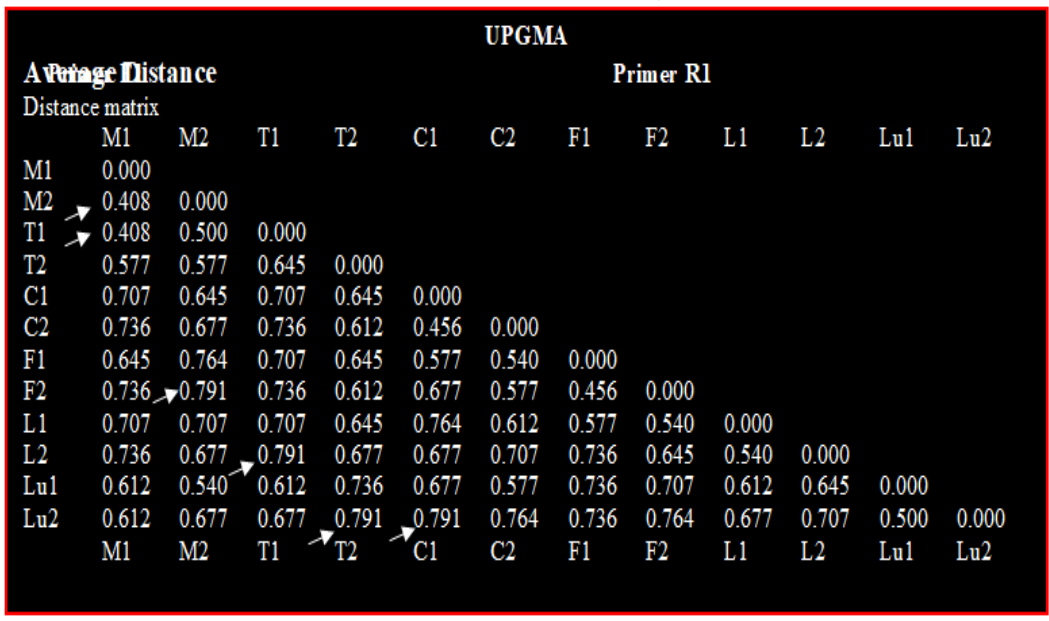

أشار الباحث Sajjad في امكانية استخدام تفاعلات مؤشرات التضاعف العشوائي نتائج التباين الوراثي ما بين إثنا عشر سلالة من بكتريا الرايزوبيا المعزولة من العقد الجذرية لنبات العدس والمزروعة في عدة مناطق تابعة لأقليم البنجاب في باكستان. اوضحت النتائج ان هناك تبايناً وراثياً ما بين هذه السلالات وانها تقع ضمن مجموعتين متميزتين A و

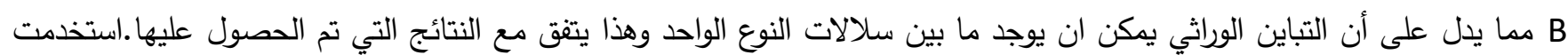
المسافات الوراثية ما بين عزلات النوع الواحد والانواع المختلفة لرسم مخطط الثجري_Dendrogram وفق طريقة UPGMA cluster analysis (الثكل 8 ) حيث تم ادخال قيم مصفوفة المسافات الوراثية في الحاسوب الالمي ضمن برنامج MVSP النسخة 3.22 [15] .

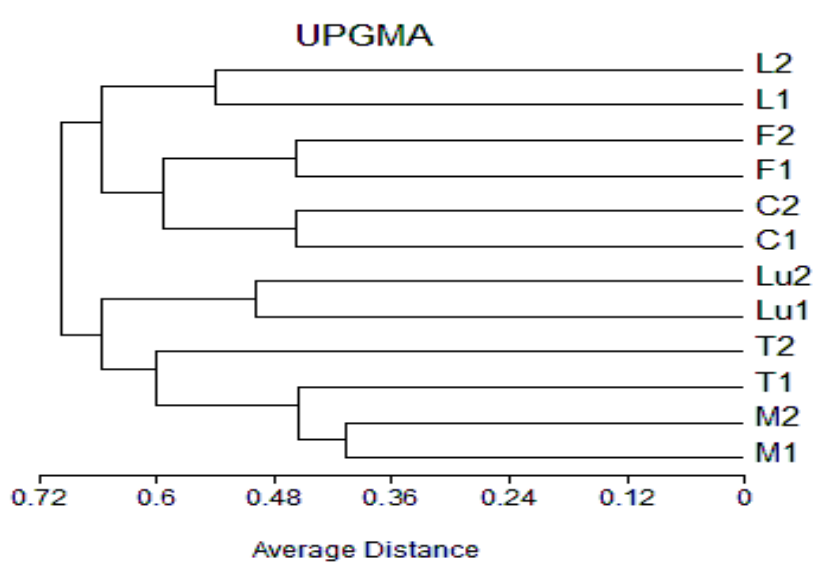

الشكل (8) مخطط الشجري لأثنى عشر عزلة تعود لستة انواع من بكتريا الرايزوبيا وذلك باستخدام تفاعلات

$$
\text { مؤشرات التضاعف العشوائي. }
$$


من مخطط التحليل التجميعي يمكن استخراج النتائج التالية والتي تتضمن وجود احد عشر عقدة تتضوي فيها عزلات من بكتريا الرايزوبيا مختلفة الاعداد وتملك قيم متباينة من الاختلاف الوراثي. يمكن وضع هذه العزلات البكتيرية قيد الدراسة ضمن مجموعتين الاولى تضم بكتريا الرايزوبيا المعزولة من العقد الجذرية لنباتات الجت والحلبة والترمس والثانية تتضوي فيها تلك المعزولة من العقد الجذرية لنباتات الحمص والباقلاء والعدس (الجدول 5).

الجدول (5) عدد العقد والمجاميع البكتيرية التي تضمها وقيم الاختلاف الوراتي لها.

\begin{tabular}{|c|c|c|c|c|}
\hline البكتيرية في العزلات & الاختلاف & المجموعة & المجموعة & العقدة \\
\hline 2 & 0.408 & $\mathrm{M} 2$ & M1 & 1 \\
\hline 3 & 0.454 & $\mathrm{~T} 1$ & العقدة 1 & 2 \\
\hline 2 & 0.456 & $\mathrm{C} 2$ & $\mathrm{C} 1$ & 3 \\
\hline 2 & 0.456 & $F 2$ & F1 & 4 \\
\hline 2 & 0.500 & Lu2 & Lu1 & 5 \\
\hline 2 & 0.540 & L2 & L1 & 6 \\
\hline 4 & 0.593 & العقدة 4 & العقدة 3 & 7 \\
\hline 4 & 0.600 & $\mathrm{~T} 2$ & العقدة 2 & 8 \\
\hline 6 & 0.657 & العقدة 5 & العقدة 8 & 9 \\
\hline 6 & 0.657 & العقدة 6 & العقدة 7 & 10 \\
\hline 12 & 0.698 & العقدة 10 & العقدة 9 & 11 \\
\hline
\end{tabular}

1- Y. M. Al-Katib. "Classification of seed plants". University of Baghdad. Dar Alwatania of Printing and Publishing, Baghdad. (1988).

2- C. Franche; K. Lindstrom and C. Elmerich "Nitrogen-fixing bacteria associated with leguminous and non-leguminous plants". Plant and Soil, 321:35-59. (2009).

3- Microbionet. Bacteriology; Rhizobiaceae. Sciencenet Multimedia Publishing house Limited, Victoria, Australia. (2005).

4- P.H. Graham. "Selective Medium for Growth of Rhizobium", Applied Microbiol. p.769-770. (1969).

5- J. M. A. Vincent . "Manual for the Practial Study of Root Nodule Bacteria. IBP Handbook" No. 15. Oxford: Blackwell Scientific Publications, Oxford, p.113-131. (1970).

6- B. Singh; R. Kaur and K. Singh. "Characterization of Rhizobium strain isolated from the roots of Trigonella foenum graecum(fenugreek)”. Afr. J. Biotech.,7(20):3671-3676. (2008).

7- J. A. Morello; P. A. Granato and, H. E. Mizer. Laboratory manual and work book in Microbiology , $7^{\text {th }}$ ed, Sprial Bound, Comb, P. 111-139. (2003).

8- E. O. King; M. K. Ward and D. E Raney. Two simple media for the demonstration of Pyocyanin and fluorescin. J. Lab. Clin. Med., 44:301-307. (1954). 
9- J. G. Cappuccino and N. Sherman "Microbiology a laboratory Manual". $5^{\text {th }}$ ed, Addison Wesley Longman, Inc.,p.133-145. (1999).

10- E. J. Baron; M. T. Pezlo and L. M. Delamaza "Color Atlas of Diagnostic Microbiology". MosbyYear Book, United Startes of America,p.25-92. (1997).

11- C. W. Strattan and Y. W. Tang. Advanced techniques in diagnostic microbiology, Springer Science and Business Media, USA, P.94-117. (2006).

12- H. J. Benson "Microbiological" $8^{\text {th }}$ ed, McGraw Hill Companies, Inc.,p.130-155. (2002).

13- R. M. Atlas; A. E. Brown and L. C. Parks "Laboratory Manual of Experimental Microbiology". Mosby-Year Book,Inc., St-Louis, U.S.A. (1995)

14- D. Freifelder, Molecular Biology. $2^{\text {th }}$ ed., Jones and Barrlett Publishers, Inc., U. S. A. (1987).

15- M. Sajjad; T. A. Malik; M. Arshad; Z. A. Zahir; F. Yusuf and S. Rahman "PCR studies on genetic diversity of rhizobial strains" Int. J. Agri. Biol., 10:505-510. (2008).

16- H. Grundman; C. Scheidre; D. Hartung; F. D. Daschner and T. L. Pitt "Descriminatory Power of three DNA Based typing techniques for P. aeruginosa" J. Clin. Microbiol. 33: 528-534. (1995).

17- C. I. Kado and S. T. Liu "Rapid procedure for detection and isolation of large and small plasmids" Bact. J. (3) 145 p. 1365-1373 (1981).

18- Gauri, S., A. K. Bhatt, R. P. Pant, S. Bedi, M. K. and Naglot, A. (2011). Journal of Agricultural Technology. Vol. 7(6): 1705-1723.

19- A. K. Deka and P. Azad "Isolation of Rhizobium strains; cultural and Biochemical characteristic". Legume Res., 29: 209-212. (2006).

20- F. Shahzad; M. Shafee; F. Abbas; S. Babar; M. M. Tariq and Z. Ahmad "Isolation and biochemical characterization of Rhizobium meliloti from root nodules of alfalfa (medico sativa)". The J. of Animal \& Plant Sciences, 22(2): 522-524.(2012).

21- M. Hussain; M. Ashraf; M. Saleem and F. Y. Hafeez "Isolation and Characterization of Rhizobial Strains From Alfalfa". Pak. J. Agri. Sci., 39:32-34. (2002).

22- G. Singh, A. K. Bhatt, R. P. Pant, S.; M. K. Bedi and A. Naglot "Journal of Agricultural Technology". Vol. 7(6): 1705-1723. (2011).

23- S. M. Wood and W. Newcomb "Nodule morphogenesis: the early infection of alfalfa (Medicago sativa) root hairs by Rhizobium meliloti". Can. J. Bot., 67: 3108-3122. (1989).

24- C. Cevheri; Kǚćk, Ḉ. and Ḉetin, Fungicide, E. "Antibiotic, Heavy Metal Resistance and Salt Tolerance of Root Nodule Isolates from Vicia palaestina" .Afr. J. Biotech. 13:2423-2429. (2011). 